\title{
Inclusion of calcium hydroxide-treated corn stover as a partial forage replacement in diets for lactating dairy cows
}

\author{
Brittany A. Casperson, ${ }^{*}$ Aimee E. Wertz-Lutz, $\nmid$ Jim L. Dunn, $\dagger$ and Shawn S. Donkin*1 \\ *Department of Animal Sciences, Purdue University, West Lafayette, IN 47907 \\ †Archer Daniels Midland Company, Animal Nutrition, Quincy, IL 62301
}

\begin{abstract}
Chemical treatment may improve the nutritional value of corn crop residues, commonly referred to as corn stover, and the potential use of this feed resource for ruminants, including lactating dairy cows. The objective of this study was to determine the effect of prestorage chopping, hydration, and treatment of corn stover with $\mathrm{Ca}(\mathrm{OH})_{2}$ on the feeding value for milk production, milk composition, and dry matter intake (DMI). Multiparous mid-lactation Holstein cows $(\mathrm{n}=30)$ were stratified by parity and milk production and randomly assigned to 1 of 3 diets. Corn stover was chopped, hydrated, and treated with $6 \% \mathrm{Ca}(\mathrm{OH})_{2}$ (as-fed basis) and stored in horizontal silo bags. Cows received a control (CON) total mixed ration (TMR) or a TMR in which a mixture of treated corn stover and distillers grains replaced either alfalfa haylage (AHsub) or alfalfa haylage and an additional portion of corn silage (AH+CSsub). Treated corn stover was fed in a TMR at 0,15 , and $30 \%$ of the diet DM for the CON, AHsub, and AH+CSsub diets, respectively. Cows were individually fed in tiestalls for 10 wk. Milk production was not altered by treatment. Compared with the CON diet, DMI was reduced when the AHsub diet was fed and tended to be reduced when cows were fed the AH+CSsub diet $(25.9,22.7$, and 23.1 $\pm 0.88 \mathrm{~kg} / \mathrm{d}$ for CON, AHsub, and AH+CSsub diets, respectively). Energy-corrected milk production per unit of DMI $(\mathrm{kg} / \mathrm{kg})$ tended to increase with treated corn stover feeding. Milk composition, energy-corrected milk production, and energy-corrected milk per unit of DMI $(\mathrm{kg} / \mathrm{kg})$ were not different among treatments for the 10-wk feeding period. Cows fed the AHsub and $\mathrm{AH}+\mathrm{CSsub}$ diets had consistent DMI over the 10-wk treatment period, whereas DMI for cows fed the CON diet increased slightly over time. Milk production was not affected by the duration of feeding. These data indicate that corn stover processing, prestorage hydra-
\end{abstract}

Received May 17, 2017.

Accepted October 10, 2017.

${ }^{1}$ Corresponding author: sdonkin@purdue.edu tion, and treatment with calcium hydroxide can serve as an alternative to traditional haycrop and corn silage in diets fed to mid-lactation dairy cows.

Key words: corn stover, alternative forage, milk fat

\section{INTRODUCTION}

Approximately 196 million tonnes of corn stover are produced annually in the United States, and sustainable removal is estimated to be 58.3 million dry tonnes (Graham et al., 2007). Quantities of harvestable corn stover are determined by land use for corn grain production, corn grain yield, soil tillage practices, soil erosion risks, and several other agronomic and economic factors (Watson et al., 2015). Recent data suggest that 30 to $60 \%$ of available corn stover could be removed annually for feed, biofuels production, and other uses without detrimental effects on land use or future crop yield (Johnson et al., 2006; Wilhelm et al., 2007; Donkin et al., 2013).

The use of corn stover as livestock feed has been limited due to inherently low digestibility. Diversion of corn stover into cellulosic biofuels production has resulted in innovation and improvements in corn stover harvesting and processing (Chang and Holtzapple, 2000; Donkin et al., 2013). Several biofuels-related technologies are adaptable and consistent with improving the digestibility of corn stover for use in ruminant diets. Furthermore, the potential use of crop residues, including corn stover, may provide strategies to maximize food production per land unit or serve as an alternative strategy to meet feed inventory needs when crop yields are compromised due to adverse climate or other challenges (USDA, 2013).

Treatment and processing of corn stover to optimize cellulosic ethanol production (Hsu et al., 1980; Chang and Holtzapple, 2000) are consistent with increasing the fermentable energy of plant biomass from lowquality feedstuffs for use by rumen bacteria. Alkaline hydrolysis using $\mathrm{NaOH}, \mathrm{NH}_{3}, \mathrm{Ca}(\mathrm{OH})_{2}, \mathrm{KOH}$, or $\mathrm{CaO}$ has been used to enhance the digestibility of corn stover and low-quality feeds (Klopfenstein and Owen, 1981; 
Watson et al., 2015). These biomass treatments alter the structure of plant fiber and consequently increase the yield of fermentable sugars for cellulosic ethanol production or rumen fermentation (Klopfenstein, 1978; Mosier et al., 2005). Calcium hydroxide appears to be a preferred treatment because it is less caustic and more economical than either sodium hydroxide or potassium hydroxide (Gandi et al., 1997).

Chemical treatment of low-quality forages has yielded mixed results in feeding studies with dairy cows. Alkaline hydrogen peroxide-treated wheat straw can replace $20 \%$ of the alfalfa haylage and corn silage in diets for lactating cows without negatively affecting milk production, composition, or feed intake, but greater inclusion of either 40 or $60 \%$ of the diet DM decreased milk production (Cameron et al., 1991). The combination of calcium oxide-treated corn stover and dried distillers grains can replace wild rye, corn silage, or corn grain to a level of $15 \%$ of diet DM without affecting DMI, milk production, or 4\% FCM yield (Shi et al., 2015). However, replacing grain in the diet with alkali-treated corn stover at $13 \%$ of the diet DM reduced DMI and milk production (Cook et al., 2016a). Furthermore, the feeding value of traditional forages may be improved with alkali treatment (Cook et al., 2016b). Alkali treatment may potentiate the value of corn stover as an alternative feedstuff, but additional efforts are necessary to determine the level of inclusion and the portion of the diet that can be replaced without negative effects on DMI and lactation performance of dairy cows.

We hypothesized that calcium hydroxide-treated corn stover could replace a portion of traditional forages in diets fed to lactating dairy cattle. The objective of the current study was to determine the effect of replacing alfalfa haylage in the diet of dairy cows with calcium hydroxide-treated corn stover and the effect of further replacement of corn silage on DMI, milk production, and milk composition. We chose these forages because they are commonly used in diets fed to dairy cattle in the Midwest region of the United States.

\section{MATERIALS AND METHODS}

\section{Treatment of Corn Stover with $\mathrm{Ca}(\mathrm{OH})_{2}$}

Corn stover was harvested in large round bales and processed through a Haybuster Big Bite 1130 tub grinder (DuraTech Industries International Inc., Jamestown, ND) using a rectangular screen $(11.4-19.1 \mathrm{~cm})$ to create a theoretical chop length of 10.2 to $15.2 \mathrm{~cm}$. Chopped corn stover was rehydrated with a slurry of $\mathrm{Ca}(\mathrm{OH})_{2}$ in water. The $\mathrm{Ca}(\mathrm{OH})_{2}$ slurry was uniformly sprayed onto the chopped corn stover as it was conveyed from the chopper to achieve $6 \% \mathrm{Ca}(\mathrm{OH})_{2}$ on an as-fed basis and a final moisture content of $50 \%$. The chopped, hydrated, and calcium hydroxide-treated corn stover was immediately packed into an Ag-Bag horizontal plastic silo (St. Nazianz, WI) and stored anaerobically for a minimum of 2 wk before feeding. Samples of the untreated corn stover were collected at the time of processing, and samples of treated corn stover were collected at feeding. Samples of untreated and treated corn stover were analyzed using wet chemistry methods by DairyOne Forage Lab (Ithaca, NY). Samples were analyzed for DM, OM (method 942.05; AOAC International, 2012), and ether extract (method 2003.05; AOAC International, 2012). Nitrogen was measured by rapid combustion using a Macro Elemental (LECO Corporation, Saint Joseph, MI) nitrogen analyzer (AOAC International, 2000). To calculate $\mathrm{CP}$, the nitrogen value was multiplied by 6.25 . The ADF was determined per AOAC International (2000) method 973.18, lignin was determined by the method of Goering and Van Soest (1970), and NDF was determined using $\alpha$-amylase and sodium sulfite (Van Soest et al., 1991). Starch was determined according to Bach Knudsen (1997; Biochemistry Analyzer, YSI Inc., Yellow Springs, OH). Minerals (Ca, P, Mg, $\mathrm{K}, \mathrm{Na}, \mathrm{Fe}, \mathrm{Zn}, \mathrm{Cu}, \mathrm{Mn}, \mathrm{Mo}$, and S) were analyzed using an inductively coupled plasma radical spectrometer (Thermo Scientific, Waltham, MA). Predicted $\mathrm{NE}_{\mathrm{L}}$ was calculated as previously described (Weiss, 1993), and NFC was determined by difference (NRC, 2001).

\section{Animals and Handling}

All procedures for animal care and use were approved by the Purdue University Animal Care and Use Committee. Mid-lactation multiparous Holstein cows ( $\mathrm{n}=$ 30) were stratified by milk production and parity and randomly assigned to 1 of 3 diets. Cows were (mean \pm SD) $123 \pm 18 \mathrm{DIM}$, weighed $627 \pm 61 \mathrm{~kg}$, were producing $37.0 \pm 8.6 \mathrm{~kg}$ of milk/d, and had a BCS of $2.91 \pm 0.26$ at the initiation of the experiment. All cows were housed in individual tiestalls at the Purdue University Dairy Research and Education Center, had free access to water, and were fed a TMR to meet or exceed NRC (2001) requirements for cows described above and producing milk containing 3.8\% fat and $3.0 \%$ true protein. Feed was delivered once daily at $0800 \mathrm{~h}$ to achieve approximately $10 \%$ daily feed refusals. Dry matter intake was monitored on a common pre-experimental diet and was $23.4 \pm 1.82 \mathrm{~kg} / \mathrm{d}$ (mean $\pm \mathrm{SEM}$ ); there were no differences in pre-experimental DMI or milk production among cows based on their assigned experimental diets. Following $7 \mathrm{~d}$ of acclimation to the facilities, cows received a control TMR 
$(\mathbf{C O N})$, a TMR in which $\mathrm{Ca}(\mathrm{OH})_{2}$-treated corn stover completely replaced alfalfa haylage and was included at $15 \%$ of the diet DM (AHsub), or a TMR in which $\mathrm{Ca}(\mathrm{OH})_{2}$-treated corn stover was included at $30 \%$ of the diet DM and completely replaced alfalfa haylage and a portion of corn silage (AH+CSsub). Wet distillers grain was primarily added with $\mathrm{Ca}(\mathrm{OH})_{2}$-treated corn stover in both the AHsub and $\mathrm{AH}+\mathrm{CSsub}$ diets to match the protein and energy content of the diets. Additional adjustments were made using soybean meal, Enertia (ADM Animal Nutrition, Quincy, IL), and corn grain. Diets were formulated to be isonitrogenous and isoenergetic to support $32.5 \mathrm{~kg} / \mathrm{d}$ based on $\mathrm{NE}_{\mathrm{L}}$ and
$38.0 \mathrm{~kg}$ of milk/d based on MP with a predicted intake of $23 \mathrm{~kg} / \mathrm{d}$. Calcium content of the diets was adjusted to similar levels primarily by the addition of calcium carbonate to the control and AHsub diets (Table 1). Cows remained on their assigned diets for $70 \mathrm{~d}$.

Diets were mixed fresh daily as a TMR. Feed intake was determined daily by difference of feed offered and refused, assuming equal DM content for feed offered and feed refused. Dietary ingredients were collected weekly, dried in a convection oven (Fisher Scientific, Hampton, $\mathrm{NH})$ at $60^{\circ} \mathrm{C}$ for $72 \mathrm{~h}$, and used for weekly adjustments to diets on an as-fed basis. Treated corn stover samples collected during the experiment and untreated

Table 1. Ingredient and chemical composition of the diets

\begin{tabular}{|c|c|c|c|}
\hline \multirow[b]{2}{*}{ Item (\% of DM unless noted) } & \multicolumn{3}{|c|}{ Treatment $^{1}$} \\
\hline & $\mathrm{CON}$ & AHsub & $\mathrm{AH}+\mathrm{CSsub}$ \\
\hline \multicolumn{4}{|l|}{ Ingredient $^{2}$} \\
\hline Corn silage & 36.00 & 36.03 & 21.08 \\
\hline Corn stover & & 15.21 & 29.94 \\
\hline Alfalfa haylage & 16.92 & & \\
\hline Corn distillers grain wet & & 7.61 & 6.16 \\
\hline High-moisture corn & 16.92 & 13.39 & 14.82 \\
\hline Soybean meal & 14.58 & 13.45 & 14.46 \\
\hline Enertia fat supplement & 0.50 & 0.30 & 1.00 \\
\hline Double S molasses dairy & 2.40 & 2.40 & 2.60 \\
\hline Soybean hulls & 2.60 & 2.60 & 2.60 \\
\hline Ground corn & 4.44 & 4.44 & 4.44 \\
\hline Urea & 0.25 & 0.31 & 0.35 \\
\hline Calcium carbonate & 2.70 & 1.50 & 0.00 \\
\hline Sodium bicarbonate & 0.65 & 0.65 & 0.65 \\
\hline Magnesium oxide & 0.20 & 0.20 & 0.20 \\
\hline Monosodium phosphate & 0.50 & 0.50 & 0.50 \\
\hline Salt & 0.40 & 0.40 & 0.40 \\
\hline Calcium sulfate & 0.20 & 0.20 & 0.00 \\
\hline Diamond V XP & 0.26 & 0.26 & 0.26 \\
\hline Vitamin E, 44,053 IU/kg & 0.02 & 0.02 & 0.02 \\
\hline Rumensin 90 & 0.01 & 0.01 & 0.01 \\
\hline OmniGen-AF & 0.13 & 0.13 & 0.13 \\
\hline PU5390 premix ${ }^{3}$ & 0.12 & 0.12 & 0.12 \\
\hline \multicolumn{4}{|l|}{ Chemical analysis $^{4}$} \\
\hline $\mathrm{CP}$ & $16.8 \pm 1.2$ & $16.9 \pm 0.7$ & $16.6 \pm 1.4$ \\
\hline $\mathrm{NDF}$ & $23.2 \pm 1.2^{\mathrm{a}}$ & $29.4 \pm 0.9^{\mathrm{b}}$ & $32.6 \pm 3.9^{\mathrm{b}}$ \\
\hline $\mathrm{ADF}$ & $16.1 \pm 0.9^{\mathrm{a}}$ & $19.5 \pm 1.4^{\mathrm{ab}}$ & $22.4 \pm 2.7^{\mathrm{b}}$ \\
\hline Lignin & $2.97 \pm 0.2$ & $2.96 \pm 0.4$ & $2.99 \pm 0.5$ \\
\hline Ash & $9.58 \pm 0.6$ & $9.60 \pm 0.4$ & $9.94 \pm 1.1$ \\
\hline $\mathrm{NE}_{\mathrm{L}}^{5}(\mathrm{Mcal} / \mathrm{kg})$ & $1.64 \pm 0.03$ & $1.57 \pm 0.03$ & $1.53 \pm 0.08$ \\
\hline NFC & $48.4 \pm 1.5^{\mathrm{a}}$ & $43.2 \pm 0.5^{\mathrm{ab}}$ & $40.5 \pm 3.7^{\mathrm{b}}$ \\
\hline $\mathrm{Ca}$ & $1.89 \pm 0.1$ & $2.04 \pm 0.2$ & $2.29 \pm 0.3$ \\
\hline $\mathrm{P}$ & $0.49 \pm 0.0$ & $0.45 \pm 0.0$ & $0.47 \pm 0.0$ \\
\hline
\end{tabular}

a,b Means within a row with different superscripts differ $(P<0.05)$.

${ }^{1} \mathrm{CON}=0 \%$ treated corn stover; AHsub $=15 \%$ treated corn stover; $\mathrm{AH}+\mathrm{CSsub}=30 \%$ treated corn stover.

${ }^{2}$ Enertia fat supplement, ADM Animal Nutrition, Quincy, IL; Double S molasses dairy, Double Sliquid feed products, Danville, IL; Diamond V XP, Diamond V, Cedar Rapids, IA; Rumensin 90, Elanco Animal Health, Greenfield, IN; OmniGen-AF, Phibro Animal Health Corporation, Teaneck, NJ.

${ }^{3}$ Contains $5.56 \% \mathrm{CP}, 65.2 \%$ ash, $4.75 \% \mathrm{Ca}, 0.05 \% \mathrm{P}, 0.03 \% \mathrm{Mg}, 0.06 \% \mathrm{~K}, 0.69 \% \mathrm{Na}, 6.28 \% \mathrm{~S}, 452 \mathrm{mg} / \mathrm{kg}$ of Co, $12,461 \mathrm{mg} / \mathrm{kg}$ of Cu, $451 \mathrm{mg} / \mathrm{kg}$ of I, $102 \mathrm{mg} / \mathrm{kg}$ of Fe, 46,297 mg/kg of Mg, 56,403 mg/kg of Zn, 5,705 $\mathrm{kIU} / \mathrm{kg}$ of vitamin $\mathrm{A}, 1,801 \mathrm{kIU} / \mathrm{kg}$ of vitamin $\mathrm{D}$, and $30,734 \mathrm{kIU} / \mathrm{kg}$ of vitamin $\mathrm{E}$.

${ }^{4}$ Means and standard deviations for 3 independent samples.

${ }^{5}$ Calculated. 
corn stover collected before treatment were ground in a Wiley mill (Thomas Scientific, Swedesboro, NJ) to pass through a 2-mm screen, subsampled, and sent to DairyOne Forage Lab for analysis as described above. Samples of TMR were collected weekly throughout the trial, dried at $60^{\circ} \mathrm{C}$ for $72 \mathrm{~h}$, and used to determine daily DMI. Daily DMI was averaged by week to determine weekly DMI before statistical analysis. Samples of TMR collected during wk 1, 4, and 7 of feeding were used to determine chemical composition of the diets. All TMR samples were sent to Cumberland Valley Analytical Services (Hagerstown, MD) for analysis. Samples were analyzed for DM and OM (method 942.05; AOAC International, 2012). Nitrogen (method 990.03; AOAC International, 2012) was determined by rapid combustion using a Macro Elemental nitrogen analyzer, and $\mathrm{CP}$ was calculated as nitrogen value was multiplied by 6.25. The ADF was determined per AOAC International (2000) method 973.18, lignin was determined by the method of Goering and Van Soest (1970), and NDF was determined using $\alpha$-amylase and sodium sulfite (Van Soest et al., 1991). Starch was determined according to Bach Knudsen (1997; Biochemistry Analyzer, YSI Inc.). Ash was determined per AOAC International (2012) method 942.05. Minerals (Ca and P) were analyzed using an inductively coupled plasma radical spectrometer (Thermo Scientific). Predicted $\mathrm{NE}_{\mathrm{L}}$ was calculated as previously described (Weiss, 1993), and NFC was determined by difference (NRC, 2001).

Cows were released from tiestalls and milked twice daily at 0500 and $1600 \mathrm{~h}$. Milk production was measured daily and averaged by week before statistical analysis. Milk samples were collected for 2 consecutive milkings during each week of the experiment and analyzed for fat, protein, lactose, solids, somatic cells, and MUN by DairyOne Forage Lab using Fourier-transform infrared spectroscopy technology for milk components; somatic cells were determined by flow cytometry. Milk composition and milk yield were used to calculate milk fat, protein, lactose, TS, and 4\% ECM yields using the equation $\mathrm{ECM}=[0.4 \times$ milk yield $(\mathrm{kg})]+[15 \times$ fat yield (kg)] as previously indicated (NRC, 2001).

Body weight and BCS were measured on a single day at the initiation and completion of the experiment. Cows were scored for body condition by 2 individuals using the 5-point body condition scoring system (Ferguson et al., 1994), and values were averaged for analysis. Change in BW and change in BCS were calculated as the difference of initial and ending values.

\section{Statistical Analyses}

Data were analyzed for normality or error variances using the PROC UNIVARIATE procedure of SAS (ver- sion 9.4; SAS Institute, Cary, NC). Data for diet nutrient analysis and analysis of untreated versus treated corn stover were analyzed using the PROC MIXED procedure of SAS using a model that accounted for feed type and sample replicate. Dry matter intake, milk production, milk composition, and ECM were determined by week of experiment using the PROC MIXED procedure of SAS, which accounted for the effects of time, treatment, and cow within time $\times$ treatment. Data for change in BW and change in BCS were analyzed using the PROC MIXED procedure of SAS and accounted for the effects of cow, treatment, and cow within treatment. Data are reported as least squares means \pm standard error of the mean. Means were evaluated using Tukey's multiple comparisons test and were considered different if $P<0.05$ and tended to differ when $0.05 \leq P \leq 0.10$.

\section{RESULTS AND DISCUSSION}

\section{Chemical Composition of Corn Stover}

Treating corn stover with calcium hydroxide reduced $(P<0.05)$ the ADF and NDF contents of the feed by 14 and $29 \%$, respectively, and tended $(P<0.10)$ to reduce lignin content by $20 \%$. The treatment process increased $(P<0.05)$ the NFC and calculated $\mathrm{NE}_{\mathrm{L}}$ contents of the feed by 233 and $217 \%$, respectively. The underlying nature of the increase in NFC for treated stover has not been examined but may reflect the action of hydroxide to produce a spectrum of cellulose breakdown products that differ in solubility in aqueous solutions (Gubitosi et al., 2017). Calcium and ash contents were increased $(P<0.05)$ as expected by 157 and $160 \%$, respectively, relative to untreated corn stover by the addition of $\mathrm{Ca}(\mathrm{OH})_{2}$ during prestorage processing (Table 2). The $\mathrm{Ca}(\mathrm{OH})_{2}$ was added to a target of $6 \%$ of the as-fed mix with stover at $50 \%$ of DM or $12 \%$ $\mathrm{Ca}(\mathrm{OH})_{2}$ on a DM basis. Given a calcium content of $54.1 \%$ in $\mathrm{Ca}(\mathrm{OH})_{2}$, this translates to $6.5 \%$ calcium on a DM basis in the final product. When added to the calcium content of untreated stover $(0.30 \%)$, we anticipated a final concentration of calcium approaching $6.9 \%$. The reported concentration of calcium in treated stover $(5.12 \pm 0.34 \%$ of $\mathrm{DM})$ indicates an application that was slightly below the target.

Chemical treatment of crop residues has been explored extensively as a method to improve the nutritive content of low-quality feeds for livestock (Klopfenstein, 1978; Watson et al., 2015). More recently, these techniques have been refined in the pretreatment of feedstocks used for biofuel production, particularly cellulosic ethanol production. The primary goal common to each scenario is the disruption of lignin structures in the crop residue and an increase in the availability of 
Table 2. Effect of $\mathrm{Ca}(\mathrm{OH})_{2}$ treatment on chemical composition of untreated and treated corn stover

\begin{tabular}{|c|c|c|}
\hline \multirow[b]{2}{*}{ Item (DM basis unless noted) } & \multicolumn{2}{|c|}{ Corn stover ${ }^{1}$} \\
\hline & Untreated & $\mathrm{Ca}(\mathrm{OH})_{2}$ treated and stored \\
\hline $\mathrm{CP}$ & $5.1 \pm 0.3$ & $5.0 \pm 0.2$ \\
\hline Adjusted CP & $5.1 \pm 0.3$ & $5.0 \pm 0.2$ \\
\hline Soluble protein $(\% \mathrm{CP})$ & $42 \pm 3$ & $35 \pm 8$ \\
\hline Crude fat & $0.7 \pm 0.1$ & $0.6 \pm 0.1$ \\
\hline $\mathrm{ADF}$ & $54.3 \pm 2.2^{\mathrm{a}}$ & $46.9 \pm 0.8^{\mathrm{b}}$ \\
\hline $\mathrm{NDF}$ & $83.3 \pm 1.1^{\mathrm{a}}$ & $59.3 \pm 3.2^{\mathrm{b}}$ \\
\hline Lignin & $7.7 \pm 0.9$ & $6.1 \pm 0.6$ \\
\hline Starch & $0.5 \pm 0.3$ & $0.4 \pm 0.1$ \\
\hline NFC & $5.2 \pm 1.1^{\mathrm{a}}$ & $17.3 \pm 3.1^{\mathrm{b}}$ \\
\hline Ash & $5.63 \pm 1.07^{\mathrm{a}}$ & $17.85 \pm 1.0^{\mathrm{b}}$ \\
\hline $\mathrm{NE}_{\mathrm{L}}^{2}(\mathrm{Mcal} / \mathrm{kg})$ & $0.35 \pm 0.07^{\mathrm{a}}$ & $0.90 \pm 0.04^{\mathrm{b}}$ \\
\hline $\mathrm{Ca}$ & $0.30 \pm 0.05^{\mathrm{a}}$ & $5.12 \pm 0.34^{\mathrm{b}}$ \\
\hline $\mathrm{P}$ & $0.06 \pm 0.01$ & $0.07 \pm 0.01$ \\
\hline $\mathrm{Mg}$ & $0.19 \pm 0.05$ & $0.21 \pm 0.02$ \\
\hline $\mathrm{K}$ & $1.07 \pm 0.08$ & $1.05 \pm 0.02$ \\
\hline $\mathrm{Na}$ & $0.006 \pm 0.003$ & $0.006 \pm 0.003$ \\
\hline $\mathrm{S}$ & $0.06 \pm 0.01$ & $0.13 \pm 0.01$ \\
\hline $\mathrm{Fe}(\mathrm{mg} / \mathrm{kg})$ & $374 \pm 215$ & $720 \pm 171$ \\
\hline $\mathrm{Zn}(\mathrm{mg} / \mathrm{kg})$ & $12 \pm 4$ & $15 \pm 3$ \\
\hline $\mathrm{Cu}(\mathrm{mg} / \mathrm{kg})$ & $5 \pm 0$ & $6 \pm 1$ \\
\hline $\mathrm{Mn}(\mathrm{mg} / \mathrm{kg})$ & $21 \pm 7$ & $33 \pm 5$ \\
\hline Mo (mg/kg) & $0.43 \pm 0.06$ & $0.55 \pm 0.07$ \\
\hline
\end{tabular}

$\overline{\mathrm{a}, \mathrm{b}}$ Means within a row with different superscripts differ $(P<0.05)$.

${ }^{1}$ Mean values and standard deviation of 3 independent samples of each feed.

${ }^{2}$ Calculated.

cellulose and hemicellulose for subsequent degradation to component sugars either by enzymatic hydrolysis during cellulosic biofuels processing (Mosier et al., 2005) or by rumen bacteria when fed as part of the diet for ruminant livestock. Pretreatment of corn stover with calcium hydroxide and subsequent storage in horizontal bag silos in the current study more than doubled the energetic value of this potential feed resource (from 0.35 to 0.90 Mcal of calculated $\mathrm{NE}_{\mathrm{L}} / \mathrm{kg}$; Table 2). The pretreatment process applied to corn stover used in the current study improved the nutrient profile of the feed resource and brought the calculated $\mathrm{NE}_{\mathrm{L}}$ content of the resulting feed to a level comparable with other lowquality forages such as wheat straw, a highly effective fiber feed that is commonly used in diets for lactating cows (Shaw et al., 2016).

\section{DMI}

There was an overall effect of diet on DMI. Dry matter intake was reduced $(P<0.05)$ for cows fed the AHsub diet compared with cows receiving the CON diet (Table 3). Similarly, there was a tendency $(P=0.08)$ for DMI to be reduced for cows fed the AH+CSsub diet. A reduction in DMI was observed previously when alkali-treated corn stover was fed in place of corn grain or wheat hay (Jami et al., 2014; Cook et al., 2016a). The addition of chaotropic agents and resulting disrup- tion of plant cell walls is accompanied by additional calcium, sodium, potassium, or other minerals. In this case, the addition of calcium hydroxide to corn stover increased the calcium content of the corn stover from 0.30 to $5.1 \%$. Dietary calcium level has been shown to affect DMI. Calcium as calcium hydroxide acts to limit feed intake of steers by almost $50 \%$ compared with the addition of anionic salts (Schauer et al., 2004). The effects of calcium to limit DMI, however, may be diminished with a duration of feeding of $90 \mathrm{~d}$ or more (Schauer et al., 2004). Dietary calcium for dairy cows at levels up to $1.8 \%$ of the diet DM does not appear to affect intake; however, higher inclusion levels were not examined (Kincaid et al., 1981). Although the total calcium content of the TMR for the current study was $2.3 \%$, the calcium hydroxide content was less than $2 \%$ of the total diet DM. In addition, the total calcium content of the diets fed in the current study was balanced by the inclusion of other calcium sources, therefore precluding dietary calcium content as the source of intake reduction when calcium hydroxide-treated corn stover was fed. Calcium sulfate was fed in the CON and AHsub diets to balance sulfur content of the diets.

Inclusion of 15 and $30 \%$ treated corn stover increased the NDF content of the diet from 23.2 to 29.4 and 32.6 for CON, AHsub, and AH+CSsub, respectively (Table 2). Although the NDF content of treated corn stover was less than that of the untreated corn stover, 
Table 3. Effect of calcium hydroxide-treated corn stover on DMI, milk yield, and efficiency of lactating cows fed the treatment diets

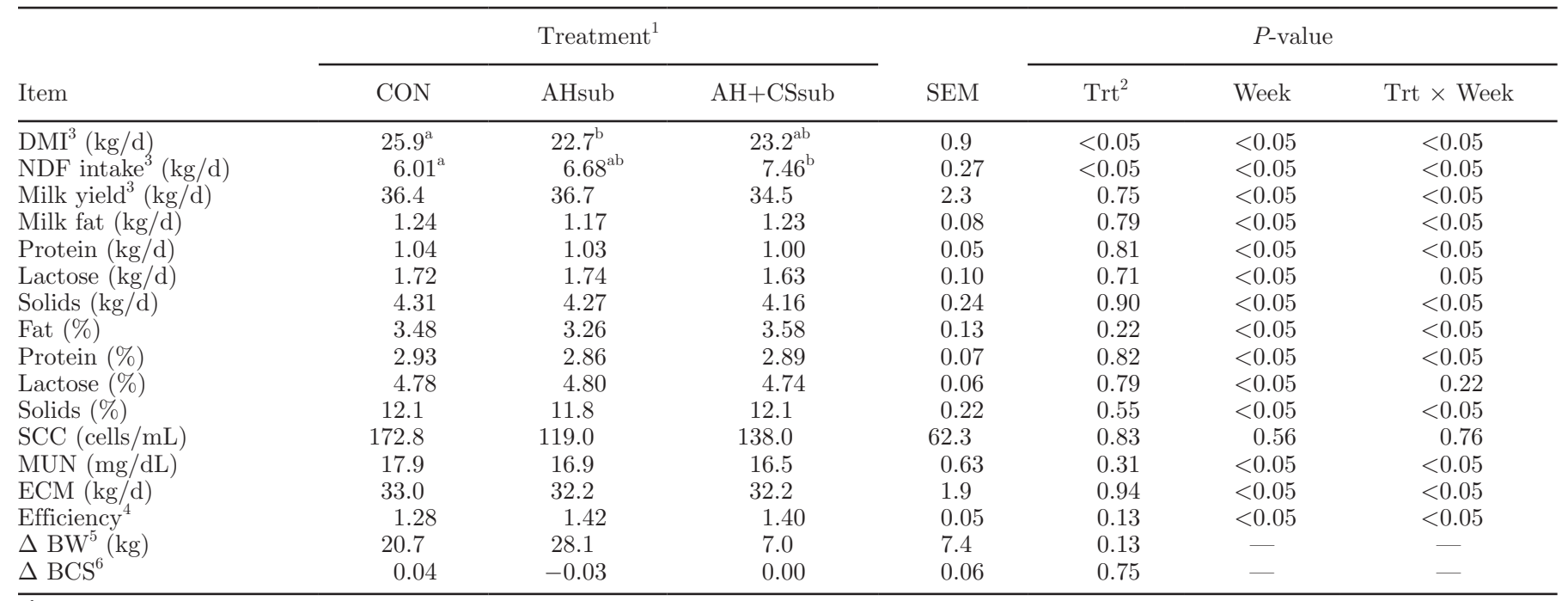

${ }^{\mathrm{a}, \mathrm{b}}$ Means within a row with different superscripts differ $(P<0.05)$.

${ }^{1} \mathrm{CON}=0 \%$ treated corn stover; AHsub $=15 \%$ treated corn stover; $\mathrm{AH}+\mathrm{CSsub}=30 \%$ treated corn stover.

${ }^{2}$ Treatment.

${ }^{3}$ Averaged by week before statistical analysis.

${ }^{4} \mathrm{ECM} / \mathrm{DMI}$.

${ }^{5}$ Change in BW.

${ }^{6}$ Change in BCS.

the reduced NDF content and substitution level were not enough to maintain a similar dietary NDF content in AHsub, $\mathrm{AH}+\mathrm{CSsub}$, and $\mathrm{CON}$ diets. The inverse relationship between forage NDF and DMI has been established previously (Mertens, 1987; Allen, 2000), and a more recent summary of 18 peer-reviewed publications indicates that increased dietary NDF from both forage or concentrate sources are negatively correlated with DMI in dairy cattle (Arelovich et al., 2008). The resulting DMI equation using diet NDF (Arelovich et al., 2008) would predict a DMI for cows fed the CON, AHsub, or AH+CSsub diets of 23.4, 22.1, and 21.4 $\mathrm{kg} / \mathrm{d}$; however, the observed DMI values were 25.9, 22.7 , and $23.2 \pm 0.9 \mathrm{~kg} / \mathrm{d}$ (mean \pm SEM; Table 2). Additionally, NDF intake was increased $(P<0.05)$ only for cows fed the AH+CSsub diet (Table 3). Although dietary NDF may negatively affect DMI (Arelovich et al., 2008), the reduction in DMI in the present study does not appear to be fully explained by differences in diet NDF content. However, the present data do not account for potential differences in NDF digestibility between the diets. Estimates of rumen and total-tract NDF digestibility are necessary to better explain the effect of calcium hydroxide-treated corn stover on feed intake.

There was an interaction effect for treatment by week of experiment on DMI (Table 3; Figure 1). Cows fed the AHsub or $\mathrm{AH}+\mathrm{CSsub}$ diets had increasing intakes during the first few weeks of the feeding period and displayed a plateau for intake toward the end of the feeding period. In contrast, the CON-fed cows had increasing intake through wk 6 and then showed a slight decline to the end of the feeding period (Figure 1). Increasing DMI with duration of feeding for cows fed the AHsub or $\mathrm{AH}+\mathrm{CSsub}$ diets containing treated corn stover suggests that palatability may be an initial factor influencing DMI, but there is increasing acceptance of the diet with duration feeding.

\section{Milk Production and Composition}

The overall yields of milk and $4 \%$ ECM were not different $(P>0.05)$ among cows fed the CON, AHsub, or $\mathrm{AH}+\mathrm{CSsub}$ diets despite differences in DMI (Table 3). Additionally, no differences were observed among the treatments for milk fat, milk protein, milk lactose, TS content, or MUN concentrations. Feeding alkali-treated forages in place of a portion of the grain in diets for lactating cows resulted in a reduction in milk yield and milk components (Cook et al., 2016a). The present data indicate a lack of effect on milk composition when calcium hydroxide-treated corn stover is used to replace other forages in the diet.

Interactions for treatment by week of experiment were observed for 4\% ECM and efficiency of $4 \% \mathrm{ECM}$ production (Table 1; Figure 1). Energy-corrected milk 

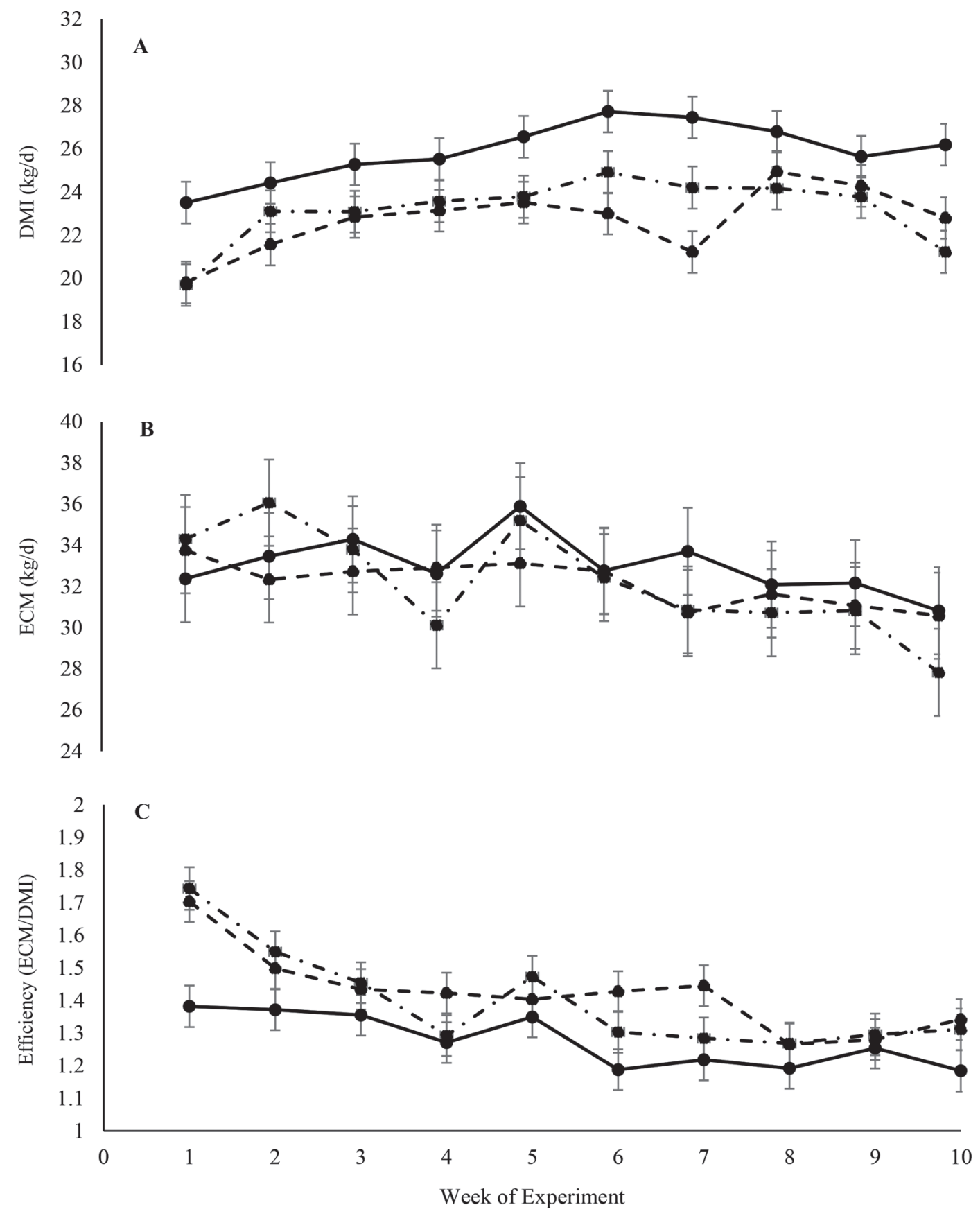

Figure 1. Effects of treatment and time of treatment on DMI, 4\% ECM, and 4\% ECM per unit of DMI. Cows were fed the control diet lacking treated corn stover (solid black line), the diet containing 15\% treated corn stover (dashed line), or the diet containing $30 \%$ treated corn stover (dashed line plus dots) for 10 wk. (A) Mean weekly DMI for cows fed the 3 diets. (B) Yield of ECM (kg/d). (C) Efficiency of ECM production during the 10-wk feeding period. Error bars represent SE of LSM.

varied by week, but a consistent pattern over the course of the experimental feeding period did not emerge for any of the treatments (Figure 1). Cows fed the AHsub or $\mathrm{AH}+\mathrm{CSsub}$ diets had lower beginning DMI than cows fed the CON diet, resulting in higher efficiency initially, but had reduced efficiency of $4 \%$ ECM dur- ing wk 2 through 9, whereas cows fed the CON diet continually decreased in efficiency.

It is important to note that direct comparison of the effects of feeding alkali-treated corn stover in place of traditional forages is complicated by the feeds included in the test diets to accommodate the shortfall in energy 
and protein content of stover relative to other forages. In the present study, a combination of treated corn stover and wet distillers grains was used to replace all of the alfalfa haylage or all of the alfalfa haylage and a portion of the corn silage. Previous research indicates that alkali-treated corn stover increases ECM yield per unit of DMI (Jami et al., 2014), and although the overall means are not statistically different, the time $\times$ treatment data for the current study support an increase in efficiency of ECM yield during the early phases of feeding treated corn stover; this advantage is reduced with duration of feeding.

Calcium hydroxide is commonly used to treat poorquality forages (Klopfenstein, 1978) but also serves as a rumen alkalizer to increase rumen $\mathrm{pH}$, especially when cows are fed rapidly fermentable feeds (Dias et al., 2012). Low ruminal $\mathrm{pH}$ can affect feed intake, microbial metabolism, and nutrient degradation (Dijkstra et al., 2012). Magnesium oxide is frequently used as an alkalizer to increase rumen $\mathrm{pH}$ and is differentiated from buffers in this regard (Erdman, 1988). Sodium hydroxide-treated wheat straw acts to increase ruminal $\mathrm{pH}$ in lactating dairy cows (Jami et al., 2014) and results in an altered structure of the rumen bacterial community toward increased fiber digestors. Specifically, the abundance of Prevotella ruminicola and Prevotella bryantii (bacteria associated with hemicellulose and glycan degradation) and the abundance of Selenomonas ruminantium (species that use lactic acid) is increased when sodium hydroxide-treated wheat straw is fed (Jami et al., 2014). Although we have not measured rumen microbial populations in this study, the potential exists for calcium hydroxide-treated corn stover to alter rumen $\mathrm{pH}$, affect changes in rumen microbial communities, and alter rumen dynamics in support of more efficient milk production.

Treatment of plant material with alkali as a pretreatment for cellulosic ethanol production and, in the case of reported here, for use as feed for dairy cows results in hydrolysis of linkages in lignin and glycosidic bonds of polysaccharides, a reduction in polymerization and crystallinity of the plant material, swelling of the fibers, and disruption of the lignin structure. Additional alkaline saponification of the acetyl and uronic ester bonds within the plant cell wall improves the accessibility of cellulases and other enzymes and degradation. The effectiveness of alkaline pretreatment is a function of changes in physical structure and chemical composition and the reaction conditions (Klopfenstein, 1978; Hsu, 1996; Mosier et al., 2005). Although pretreatment of plant material, including alkali pretreatment, disrupts the structure of lignin, the persistence of lignin in the treated material can result in a reduction of subsequent digestion of the treated material due to the high adsorption coefficient of the cellulase enzyme to lignin and inhibition of activity of cellulase (Lu et al., 2016). Soluble proteins, including BSA, are effective blocking agents for the nonproduction adsorption of cellulase to lignin in pretreated plant biomass used for biofuels production (Bhagia et al., 2017). The inclusion of distillers grains, soybean meal, and other proteins in the AHsub and $\mathrm{AH}+\mathrm{CSsub}$ diets may provide a similar blocking effect for plant polymers and promote greater rumen cellulase activity and digestibility of treated corn stover. To achieve the most efficient digestion of corn stover in the rumen of dairy cattle, it may be necessary to evaluate the effectiveness of feed protein sources that complement cellulase activity.

Taken together, utilizing treated corn stover in the diet at a 15 or $30 \%$ inclusion level in combination with distillers grains to replace alfalfa haylage or an additional portion of corn silage can provide an outlet to utilize corn stover material and a move toward maximizing land resources for animal source food production. Because milk production and composition were not changed by the inclusion of treated corn stover, there is an expectation that feeding corn stover may offer an economic advantage provided that the costs associated with treated corn stover inclusion in the diet are at least similar to the use of traditional forage sources. Data that integrate the agronomic costs associated with corn stover harvest, costs of feed processing, and the value of other feeds in the ration coupled with the value of milk produced are necessary to determine the full economic potential of calcium hydroxide-treated corn stover as a feed for lactating dairy cows. Opgrand (2015) estimated feed cost, including costs associated with acquiring, transporting, and handling each feed. Treated corn stover, corn silage, alfalfa haylage, wet distillers grains, and high-moisture corn were estimated at US\$119.78, \$138.42, \$222.47, \$218.80, and \$247.91 per dry tonne, respectively. Although many factors such as market demand and production influence feed cost, income over feed cost (IOFC) can be expected to increase by replacing higher priced ingredients if milk production can be maintained. By taking into account the cost of each ingredient of the CON, AHsub, and $\mathrm{AH}+\mathrm{CSsub}$ diets, IOFC were US $\$ 6.44, \$ 7.89$, and $\$ 6.80$ per cow per day, respectively. These improvements in IOFC agree with the results of others who have found improved IOFC with the inclusion of alkaline-treated corn stover (Shi et al., 2015). In the current study, the increased IOFC for diets containing treated corn stover is a result of the reduced ingredient costs associated with those diets and a reduction in overall feed consumption coupled with a lack of difference in 
milk production or composition. Therefore, the IOFC for rations containing treated corn stover is favorable given the costs of other feeds needed to balance the nutrient profile of the ration when corn silage or alfalfa haylage are removed. Additional analysis is needed to determine the economic viability of using treated corn stover under a wide range of production and feeding scenarios. Likewise, the overall agronomic cost:benefit ratio must be considered when considering widespread harvest of stover and use of treated corn stover as a feed (Opgrand, 2015).

\section{CONCLUSIONS}

Data from the present study demonstrate that alkalitreated corn stover can replace alfalfa haylage up to $15 \%$ of the diet DM or can replace the combination of alfalfa haylage and a portion of the corn silage up to a level of $30 \%$ of the diet DM with no negative effects on milk production or milk composition. Corn stover has limited use as a potential feed resource for lactating dairy cows given its inherently low nutritional value. Improvements in technology supporting the production of cellulosic ethanol from crop residues have led to a renewed interest in processing and treating corn stover as a feed resource for livestock. Data from the current study indicate that calcium hydroxide-treated corn stover, when combined with distillers grains, can replace alfalfa haylage and a portion of the corn silage in diets for mid-lactation dairy cows. There are indications that the inclusion of treated corn stover up to $30 \%$ of the diet DM may enhance the efficiency of milk production by reducing feed intake without any negative effects on milk production or milk composition. Furthermore, the inclusion of treated corn stover could improve IOFC in some production settings.

\section{REFERENCES}

Allen, M. S. 2000. Effects of diet on short-term regulation of feed intake by lactating dairy cattle. J. Dairy Sci. 83:1598-1624.

AOAC International. 2000. Official Methods of Analysis. 17th ed. AOAC International, Arlington, VA.

AOAC International. 2012. Official Methods of Analysis. 19th ed. AOAC International, Arlington, VA.

Arelovich, H. M., C. S. Abney, and J. A. Vizcarra. 2008. Effects of dietary neutral detergent fiber on intakes of dry matter and net energy by dairy and beef cattle: Analysis of published data. Prof. Anim. Sci. 24:375-383.

Bach Knudsen, K. E. 1997. Carbohydrate and lignin contents of plant materials used in animal feeding. Anim. Feed Sci. Technol. 67:319338.

Bhagia, S., R. Kumar, and C. E. Wyman. 2017. Effects of dilute acid and flowthrough pretreatments and BSA supplementation on enzymatic deconstruction of poplar by cellulase and xylanase. Carbohydr. Polym. 157:1940-1948. https://doi.org/10.1016/j.carbpol .2016.11.085.
Cameron, M. G., G. C. Fahey Jr., J. H. Clark, N. R. Merchen, and L. L. Berger. 1991. Effects of feeding alkaline hydrogen peroxidetreated wheat straw-based diets on intake, digestion, ruminal fermentation, and production responses by mid-lactation dairy cows. J. Anim. Sci. 69:1775-1787.

Chang, V. S., and M. T. Holtzapple. 2000. Fundamental factors affecting biomass enzymatic reactivity. Appl. Biochem. Biotechnol. 84-86:5-37. https://doi.org/10.1385/ABAB:84-86:1-9:5.

Cook, D. E., R. W. Bender, K. J. Shinners, and D. K. Combs. 2016b. The effects of calcium hydroxide-treated whole-plant and fractionated corn silage on intake, digestion, and lactation performance in dairy cows. J. Dairy Sci. 99:5385-5393. https://doi.org/10.3168/ jds.2015-10402.

Cook, D. E., D. K. Combs, P. H. Doane, M. J. Cecava, and M. B. Hall. 2016a. The effects on digestibility and ruminal measures of chemically treated corn stover as a partial replacement for grain in dairy diets. J. Dairy Sci. 99:6342-6351. https://doi.org/10.3168/ jds.2015-10403.

Dias, A. M., M. L. Itavo, J. C. Damasceno, G. Tadeu dos Santos, E. Nogueira, and C. C. Ítavo. 2012. Ruminal parameters of bovines fed diets based on sugar cane with doses of calcium hydroxide. Rev. Bras. Zootec. 41:963-969.

Dijkstra, J., J. L. Ellis, E. Kebreab, A. B. Strathe, S. López, J. France, and A. Bannik. 2012. Ruminal pH regulation and nutritional consequences of low pH. Anim. Feed Sci. Technol. 172:22-33.

Donkin, S. S., P. H. Doane, and M. J. Cecava. 2013. Expanding the role of crop residues and biofuel co-products as ruminant feedstuffs. Anim. Front. 3:54-60. https://doi.org/10.2527/af.2013-0015.

Erdman, R. A. 1988. Dietary buffering requirements of the lactating dairy cow: A review. J. Dairy Sci. 71:3246-3266.

Ferguson, J. D., D. T. Galligan, and N. Thomsen. 1994. Principal descriptors of body condition score in Holstein cows. J. Dairy Sci. 77:2695-2703.

Gandi, J., M. T. Holtzapple, A. Ferrer, F. Michael. Byers, N. D. Turner, M. Nagwani, and S. Chang. 1997. Lime treatment of agricultural residues to improve rumen digestibility. Anim. Feed Sci. Technol. 68:195-211.

Goering, H. K., and P. J. Van Soest. 1970. Forage fiber analysis (apparatus, reagent, procedures and some applications). Agric. Handbook No. 379. USDA Agricultural Research Service, Washington, DC

Graham, R. L., R. Nelson, J. Sheehan, R. D. Perlack, and L. L. Wright. 2007. Current and potential U.S. corn stover supplies. Agron. J. 99:1-11. https://doi.org/10.2134/agronj2005.0222.

Gubitosi, M., P. Nosrati, M. Koder Hamid, S. Kuczera, M. A. Behrens, E. G. Johansson, and U. Olsson. 2017. Stable, metastable and unstable cellulose solutions. R. Soc. Open Sci. 4:170487.

Hsu, T. A. 1996. Pretreatment of biomass. Pages 179-212 in Handbook on Bioethanol, Production and Utilization. C. E. Wyman, ed. Taylor and Francis, Washington, DC.

Hsu, T. A., M. R. Ladisch, and G. T. Tsao. 1980. Alcohol from cellulose. Chemtech 10:315-319.

Jami, E., N. Shterzer, E. Yosef, M. Nikbachat, J. Miron, and I. Mizrahi. 2014. Effects of including $\mathrm{NaOH}$-treated corn straw as a substitute for wheat hay in the ration of lactating cows on performance, digestibility, and rumen microbial profile. J. Dairy Sci. 97:1623-1633. https://doi.org/10.3168/jds.2013-7192.

Johnson, M. F., R. R. Allmaras, and D. C. Reicosky. 2006. Estimating source carbon from crop residues, roots and rhizodeposits using the national grain-yield database. Agron. J. 98:622-636.

Kincaid, R. L., J. K. Hillers, and J. D. Cronrath. 1981. Calcium and phosphorus supplementation of rations for lactating cows. J. Dairy Sci. 64:754-758.

Klopfenstein, T. 1978. Chemical treatment of crop residues. J. Anim. Sci. $46: 841-848$.

Klopfenstein, T., and F. G. Owen. 1981. Value and potential use of crop residues and by-products in dairy rations. J. Dairy Sci. 64:1250-1268.

Lu, X., X. Zheng, X. Li, and J. Zhao. 2016. Adsorption and mechanism of cellulase enzymes onto lignin isolated from corn stover pre- 
treated with liquid hot water. Biotechnol. Biofuels 9:118. https:// doi.org/10.1186/s13068-016-0531-0.

Mertens, D. R. 1987. Predicting intake and digestibility using mathematical models of ruminal function. J. Anim. Sci. 64:1548-1558.

Mosier, N., C. Wyman, B. Dale, R. Elander, Y. Y. Lee, M. Holtzapple, and M. Ladisch. 2005. Features of promising technologies for pretreatment of lignocellulosic biomass. Bioresour. Technol. 96:673-686.

NRC. 2001. Nutrient Requirements of Dairy Cattle. 7th rev. ed. National Academy Press, Washington, DC.

Opgrand, J. J. 2015. Lime-treated corn stover as a livestock feed input: Economic and environmental implications. MS Thesis. Purdue University, West Lafayette, IN.

Schauer, C. S., G. P. Lardy, W. D. Slanger, M. L. Bauer, and K. K. Sedivec. 2004. Self-limiting supplements fed to cattle grazing native mixed-grass prairie in the northern Great Plains. J. Anim. Sci. 82:298-306.

Shaw, C. N., M. Kim, M. L. Eastridge, and Z. Yu. 2016. Effects of different sources of physically effective fiber on rumen microbial populations. Animal 10:410-417.
Shi, H. T., S. L. Li, Z. J. Cao, Y. J. Wang, G. M. Alugongo, and P. H. Doane. 2015. Effects of replacing wild rye, corn silage, or corn grain with $\mathrm{CaO}$-treated corn stover and dried distillers grains with solubles in lactating cow diets on performance, digestibility, and profitability. J. Dairy Sci. 98:7183-7193. https://doi.org/10.3168/ jds.2014-9273.

USDA. 2013. Crop Production 2012 Summary (January 2013). National Agricultural Statistics Service, Washington, DC.

Van Soest, P. J., F. B. Robertson, and B. A. Lewis. 1991. Methods for dietary fiber, neutral detergent fiber, and nonstarch polysaccharides in relation to animal nutrition. J. Dairy Sci. 74:3583-3597.

Watson, A. K., J. C. MacDonald, G. E. Erickson, P. J. Kononoff, and T. J. Klopfenstein. 2015. Forages and pastures symposium: Optimizing the use of fibrous residues in beef and dairy diets. J. Anim. Sci. 93:2616-2625. https://doi.org/10.2527/jas.2014-8780.

Weiss, W. P. 1993. Predicting the energy values of feeds. J. Dairy Sci. $76: 1802-1811$

Wilhelm, W. W., J. M. F. Johnson, D. L. Karlen, and D. T. Lightle. 2007. Corn stover to sustain soil organic carbon further constrains biomass supply. Agron. J. 99:1655-1667. 